\title{
The World Saffron and Crocus collection: strategies for establishment, management, characterisation and utilisation
}

\author{
José-Antonio Fernández • Omar Santana $\cdot$ José-Luis Guardiola $\cdot$ Rosa-Victoria Molina \\ Pat Heslop-Harrison • George Borbely • Ferdinando Branca • Sergio Argento • \\ Eleni Maloupa · Thierry Talou · Jean-Marie Thiercelin · Khalil Gasimov • \\ Hasan Vurdu • Marta Roldán · Marcela Santaella • Enrique Sanchís • \\ Amparo García-Luis • Gyula Suranyi • Attila Molnár • Gabor Sramko • \\ Gergely Gulyas · Luckacs Balazs • Orsolya Horvat • María-Fernanda Rodríguez • \\ Raúl Sánchez-Vioque $\cdot$ Miguel-Ángel Escolano $\cdot$ José-Vicente Reina • \\ Nikos Krigas · Teresa Pastor • Begoña Renau-Morata • Christine Raynaud • \\ Oruc Ibadli • Moschos Polissiou - Maria Z. Tsimidou - Athanasios Tsaftaris • \\ Mahmoud Sharaf-Eldin · Joaquin Medina · Theophanis Constantinidis • \\ Theophanis Karamplianis • Marcelino De-Los-Mozos-Pascual
}

Received: 26 March 2010/Accepted: 12 August 2010/Published online: 19 September 2010

(C) The Author(s) 2010. This article is published with open access at Springerlink.com

\begin{abstract}
Since 2007, the European Commission AGRI GEN RES 018 "CROCUSBANK” action has permitted the creation of the alleged World Saffron and Crocus Collection (WSCC), a unique collection which contains a representation of the genetic variability present in saffron crop and wild relatives at global scale. At present the germplasm collection, housed at the Bank of Plant Germplasm of Cuenca
\end{abstract}

J.-A. Fernández $(\bowtie) \cdot$ M. Roldán · M. Santaella

Laboratorio De Biotecnología-IDR, Universidad de

Castilla-La Mancha (UCLM), Campus Universitario s/n, 02071 Albacete, Spain

e-mail: joseantonio.fperez@uclm.es

O. Santana · M.-F. Rodríguez · R. Sánchez-Vioque ·

Miguel-ÁngelEscolano · J.-V. Reina .

T. Pastor · M. De-Los-Mozos-Pascual $(\bowtie)$

Junta de Comunidades de Castilla La-Mancha (JCCM),

Centro de Investigación Agraria de Albaladejito, Ctra.

Toledo-Cuenca, km 174, 16194 Cuenca, Spain

e-mail: mde@jccm.es

J.-L. Guardiola · R.-V. Molina · E. Sanchís ·

A. García-Luis · B. Renau-Morata

Departamento de Producción Vegetal, ETSIA,

Universidad Politécnica de Valencia (UPVLC),

Camino de Vera s/n, 46022 Valencia, Spain
(BGV-CU, Spain), consists of 572 preserved accessions representing 47 different Crocus species (including saffron Crocus) and is expected to increase up to more than 600 accessions by the end of CROCUSBANK action (May 2011). The preserved biodiversity of saffron (Crocus sativus L.) covers a wide range of the genetic variability of the crop and

\footnotetext{
P. Heslop-Harrison

Department of Biology, University of Leicester (ULEIC),

University Road, Leicester LE1 7RH, UK

G. Borbely · G. Suranyi · A. Molnár · G. Sramko ·

G. Gulyas · L. Balazs · O. Horvat

Laboratory of Plant Biology, University of Debrecen

(UD), Egyetem tér 1, 4032 Debrecen, Hungary

F. Branca $\cdot$ S. Argento

Dipartimento di OrtoFloroArboricoltura e Tecnologie

Agroalimentari, Universitá di Catania (UNICT),

Via Valdisavoia, 5, 1/95123 Catania, Italy

E. Maloupa $\cdot$ N. Krigas

National Agricultural Research Foundation (NAGREF),

Agricultural Research Centre of Northern Greece,

P.O.Box 458, 57001 Thermi, Thessaloniki, Greece
} 
currently consists of 220 accessions from 15 countries: 169 of these come from European cultivation countries, 18 from commercial areas in non EU countries, 26 from regions of minimal or relict production and/or from abandoned fields and 7 from commercial nurseries. The non-saffron Crocus collection currently comprises 352 accessions: 179 collected from the wild in 12 countries of natural distribution, 24 from donations of public and private institutions, 91 from commercial nurseries and 58 acquired from BGV-CU collection management. Here we provide a record of collections, activities concerns and current strategies for documentation, conservation, characterisation, and management of the collection as important tools for researchers with interest in these valuable genetic resources.

Keywords Genetic resources - Database - Crop diversity $\cdot$ Ex situ conservation

\section{Introduction}

One of the main goals of the Convention on Biological Diversity (CBD 1993) is to achieve a

T. Talou · C. Raynaud

Institut National Polytechnique de Toulouse (INPT), Laboratoire de Chimie Agro-industrielle, 118 route de Narbonne, 31077 Toulouse, France

J.-M. Thiercelin

TRADIMPEX JM THIERCELIN SAS (TJMT), 3, rue Pierre et Marie Curie, ZAE de l'Ormeau, BP 90108, 77382 Combs La Ville, France

K. Gasimov · O. Ibadli

Institute of Botany, Azerbaijan National Academy of Sciences (ANAS), Z. Khaliliov St., 59/40, AZ 1141

Baku, Azerbaijan

H. Vurdu

Kastamonu University (KU), Faculty of Forestry, Pirlaklar Mevkii, 37200 Kastamonu, Turkey

M. Polissiou

Department of Science, Laboratory of Chemistry, Agricultural University of Athens (AUA), Iera Odos /5, 11855 Athens, Greece

\section{N. Krigas}

School of Biology, Department of Botany, Aristotle University of Thessaloniki (AUTH), University Campus, 54124 Thessaloniki, Greece significant reduction of the current rate of biodiversity loss, including plant taxa more or less closely related with species of direct socio-economic importance such as food, medicinal, condiments, ornamental, etc. (Maxted et al. 2007). A major step towards achieving this goal is improving efforts for systematic conservation of plant genetic resources, to ensure adequate and representative diversity for future uses including breeding programmes.

Crocus L. belongs to the subfamily Crocoideae, the largest of the four subfamilies currently recognized in Iridaceae family (Goldblatt et al. 2006). The genus consists of 88 small, corm-bearing, perennial species distributed in Central and Southern Europe, North Africa, and from Southwest Asia to Western China (Mathew 1982; Petersen et al. 2008) and are highly prized as garden plants for their colourful flowers, horticultural varieties, for industrial applications and as unique collector's items (Rashed-Mohassel 2007; Petersen et al. 2008). The majority of taxa (species and subspecies) are restricted to Turkey and the Balkan Peninsula. Greece alone is homeland of ca. $40 \%$ of the world's wild Crocus diversity (Tsoktouridis et al. 2009) while a total of 32 species (18 of them being endemic) are included in Turkey's

\section{Z. Tsimidou}

Department of Chemistry, Aristotle University of

Thessaloniki (AUTH), University Campus, 54124

Thessaloniki, Greece

A. Tsaftaris

Department of Genetics \& Plant Breeding, Aristotle University of Thessaloniki (AUTH), University Campus, 54124 Thessaloniki, Greece

M. Sharaf-Eldin

Medicinal and Aromatic Plants Department,

National Research Centre (NRC), 33 Elbehoth St,

Dokki Cairo-12622, Egypt

J. Medina

Centro de Biotecnología y Genómica de Plantas (CBGP),

U.P.M. - I.N.I.A, Campus de Montegancedo, 28223

Pozuelo de Alarcón, Madrid, Spain

T. Constantinidis - T. Karamplianis

Faculty of Biology, Department of Ecology and Systematics, National and Kapodistrian University of Athens, Panepistimiopolis 1578, Athens, Greece 
flora (Arslan et al. 2007). Several countries have also representatives of some Crocus species including Italy (10 species), Spain (6 species), Hungary (6 species), and others.

The genus is primarily known by $C$. sativus, commercially cultivated for the production of the spice saffron (Fernández 2004). Saffron is a highvalue, sustainable crop where improvement is possible through exploitation of biodiversity, and it contains many novel or poorly characterized bioactive molecules consistent with its use as a spice and medicinal supplement over thousands of years (Abdullaev 2002, 2004; Abdullaev and Espinosa-Aguirre 2004; Radjabian et al. 2009; Dalezis et al. 2009). Saffron spice is made from the dried stigmas of the saffron flower (C. sativus), a triploid sterile plant species that is vegetatively propagated by means of corms (vulgarly called bulbs or "onions"). Because corm multiplication does not induce genome variations with the exception of random mutations that in a triploid saffron population are not easily detectable, it is supposed that saffron material should be similar around the world. Although different commercial products are known that possibly suggests the existence of different saffron ecotypes or commercial varieties, nevertheless, the actual genetic variability present in C. sativus at worldwide scale still remains unknown. There is a general suspicion regarding the existence of scarce variation, but no serious effort has been carried out to ascertain this important issue until recently when the CROCUSBANK initiative arose (http://www.crocusbank.org).

The decrease of land surface dedicated to saffron crop in many areas has possibly resulted in corresponding genetic erosion that adds up to the limited genetic variation suspected for $C$. sativus due to its sterile habit. Thus, the situation seems dramatic at present time and compromises any attempt of genetic improvement regarding this highly-valued crop (Fernández 2004, 2007; De-Los-Mozos-Pascual et al. 2010a, b). Consequently, the creation of a germplasm bank of this species can be considered as a great achievement in the first place. In addition, the inclusion of wild species related have proved useful to saffron improvement as sources of a variety of valuable traits taking into account that the wild portion of a crop genepoll generally contains much greater genetic variation than that contained in the cultivated taxa (Khoury et al. 2010).

\section{Materials and methods}

\section{Collecting expeditions}

In order to gather a good representation of the plausible genetic variability present in the saffron crop, the collecting places were subdivided in (a) zones of commercial cultivation of saffron (EU countries and outside EU) including Protected Denomination of Origin (DOP) and (b) worldwide zones of remaining yields of saffron spice including several abandoned fields. To collect samples of saffron allies (Crocus spp.) four sources of germplasm were exploited: (a) from the wild (natural populations), (b) from botanical gardens, (c) from commercial nurseries and (d) from BGV-CU collection management (seeds).

\section{Conservation strategies}

\section{Experimental farm}

The collection is housed at the Bank of Plant Germplasm of Cuenca (BGV-CU, Spain). The experimental farm is located in the latitude and longitude $40^{\circ} 04^{\prime} 08.17^{\prime \prime} \mathrm{N}$ and $2^{\circ} 11^{\prime} 57.07^{\prime \prime} \mathrm{W}$, respectively, with altitude between 950 and $1,000 \mathrm{~m}$, average annual temperature of $11.5^{\circ} \mathrm{C}$, and precipitation ranging from 550 to $600 \mathrm{~mm}$ mainly concentrated in spring and autumn. The edaphic characteristics in the plot are typical of the area with sandy loams, alkaline $\mathrm{pH}$ (7.6-8.4), normal electric conductivity ( $<400 \mathrm{nmhos} /$ $\mathrm{cm})$ and low content in organic matter $(1-2.5 \%)$.

\section{Ex situ conservation and multiplication}

Genetic materials are preserved in the form of corms (saffron and wild relatives) and seeds (only wild species). General conservation and multiplication strategies for the collections are the standards for international genebanks outlined by Engels and Visser (2003). In addition, specific strategies and bank design for the ex situ conservation were established mainly based on information regarding the source of the species, reproductive biology, mode of multiplication, sample type and objectives of the collection. The design comprises three main collections: 
1. Reserve Vegetative Collection (saffron and allies): 10 corms of each accession were sown in special flower-pots with substrate of the collecting zone and/or specific mixture (soil enriched with organic matter mixed with sand) and placed in a greenhouse with semi-controlled conditions. Irrigation and weeding were done by hand when necessary.

2. Exchange vegetative Collection (saffron and allies): The accessions (40 corms each) were sown in the experimental farm (field conditions) in a $10-15 \mathrm{~cm}$ furrow, with $15 \mathrm{~cm}$ among plants and $50 \mathrm{~cm}$ among furrows. Conventional labouring was used to prepare soil for seeding and previous fertilization applying N (80 UF), P (100 UF) and K (100 UF) was carried out. Irrigation schedule was applied depending on the climatic conditions.

3. Seed collection (wild Crocus): The acquired seeds both from the wild and from seed harvesting in BGV-CU were placed in hermetic jars including silica gel inside and stored in a refrigerated chamber at $4^{\circ} \mathrm{C}$ and $30 \%$ relative humidity.

\section{Documentation}

\section{Descriptors definitions}

In order to facilitate retrieval and updating of information, descriptors were grouped attending to the categories proposed by Bioversity (Bioversity International 2007): passport (accession, collecting, ethnobotanical data), management, site and environment and characterisation. Passport, site and environment descriptors were adapted from the multicrop passport descriptors (MCPD) proposed by Bioversity with the inclusion of three specific descriptors: registry of income (hyperlink field), intermediary (in the acquisitions process) and photo (Ole object). Two groups of descriptors for management, seed management descriptors and vegetative management descriptors, were adapted and/or newly defined. In both cases (saffron and its wild relatives), passport information was gathered through formal Collecting Form Sheet accompanying each accession during the acquisitions process (collecting, donations, etc.) and available for download from http://www.crocus bank.org.
Central information system for Crocus germplasm

Documentation and management of the collection have been running through the Central Information System (CIS), a comprehensive electronic platform that provides an interactive documentation system including relational database and a web interface. The CIS has been developed using $\mathrm{html}$ and asp pages (Macromedia Dreamweaver ${ }^{\odot} \mathrm{CS} 4$ ) as a front-end application and MSAccess ${ }^{\circledR} 2007$ as a back-end application.

\section{Characterisation and evaluation}

First, we defined a list of descriptors valid for the genus Crocus, based on the revision of taxonomic criteria for the genus (Mathew 1977, 1982), as well as our experience of research team involved and the preliminary characterisation assays carried out (De-LosMozos-Pascual et al. 2010c). We also took into account the categories present in other Bioversity lists of descriptors (http://www.bioversityinternational.org).

Regarding to characterisation, we have currently evaluated 100 accessions, including 66 saffron accessions from different origins (Azerbaijan, France, India, Iran, Italy, Morocco, New Zealand, Spain and Turkey) and 34 other Crocus accessions from 21 different species. For these purposes, a randomized block design, with three blocks and ten corms per accession and block has been followed in the facilities of BGV-CU.

Present germplasm activities and procedures

In agreement with Khoury et al. (2010), among the most important current issues regarding the conservation and use of plant genetic resources in the BGV-CU are: acquisition of germplasm (collecting), multiplication and conservation, documentation (information systems), definition of crop descriptors, characterisation and user priorities (supplying). A view of the main activities carried out in the BGV-CU is shown in Fig. 1.

Germplasm acquisition

The development of efficient collecting strategies depends on the extent of the information of the type of genetic variation in target populations of taxa and their distribution in the target geographical region (Upadhyaya et al. 2006, 2008). Therefore, the genetic diversity of the saffron crop in the farmer field, relict 
$\mathbf{a}$

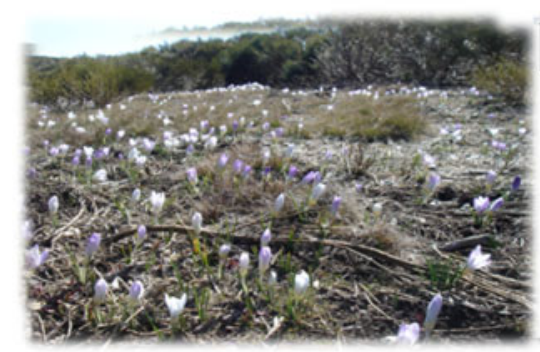

d

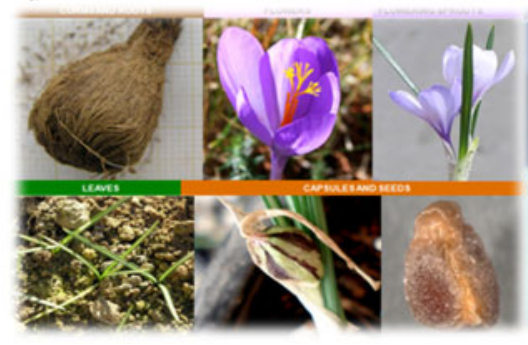

Fig. 1 Major activities at BGV-CU: a Collecting, b Documentation through the Collecting Form and the Central Information System (http://www.crocusbank.org), c Ex situ conservation

zones or abandoned fields has been complemented with the diversity present in the relatives of the crop (Crocus spp., see Fig. 2).

\section{Collecting expeditions}

Since 2006, eighty-one (81) acquisition trips have been made to collect saffron accessions (Table 1). The results of exploration and collection have yielded saffron germplasm from commercial areas in EU countries (5 countries, 169 accessions), from commercial areas in other non-EU countries ( 7 countries, 18 accessions) and from zones of remaining minimal or relict productions ( 5 countries, 26 accessions). The acquired materials cover a wide range of the genetic variability of the crop. The maintenance of accessions from relict areas is an effort to rescue the germplasm that has been lost due to the reduction of land surface dedicated to the saffron crop in the last decades.

In addition, as a result of a large-scale international collecting effort, during the period 2006-2009, one hundred and one (101) expeditions, lasting from 1 to 4 days each, were carried out covering phytogeographical regions of 10 countries where wild Crocus taxa have been documented (Table 2). Two hundred and forty six (246) accessions, belonging to thirty-one (31) different Crocus taxa (only species) were acquired c

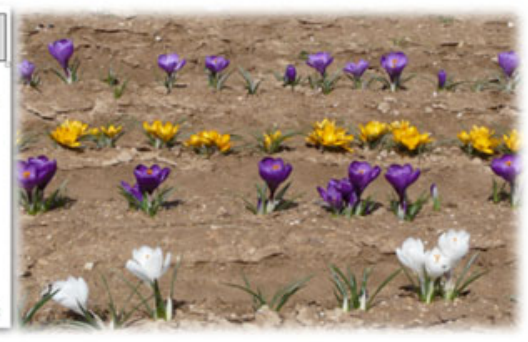

f
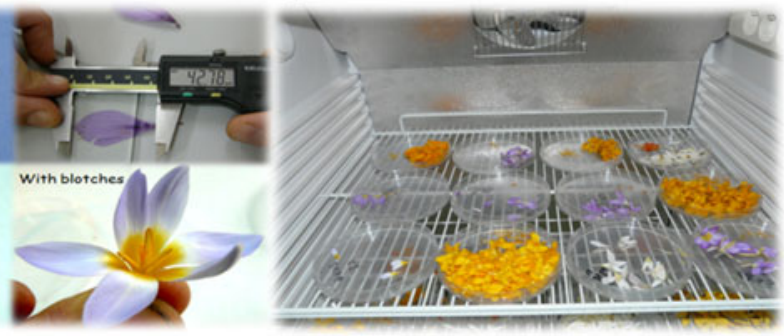

and multiplication d Descriptors definition, e Characterisation, and $\mathbf{f}$ Management of germplasm materials for supplying

as the result of the mentioned effort. At this stage, it is reasonable to indicate that germplasm collection has a good representation of the wild Crocus germplasm of plausible utility in saffron breeding. However, wild relatives are increasingly valued and the consciousness of the need for more extensive collecting must be a permanent goal (Khoury et al. 2010).

\section{Germplasm donations}

Twenty-four (24) accessions corresponding to 13 Crocus species (subspecific taxonomic categories and commercial cultivars are not included in the statistics) have been acquired through donations from cultivated samples in botanical gardens. Three target Crocus taxa missed in collecting expeditions (C. kotschyanus, C. ochroleucus and C. cancellatus) were recently included in the collection through donations from botanic gardens (Table 3). Additional efforts such as contacting with private companies, traditional cultivators and producers, rendered donations of another 11 saffron accessions (Table 4).

\section{Acquisition from nurseries}

A total of ninety-one (91) accessions from the most reputed nurseries worldwide have been acquired. As 

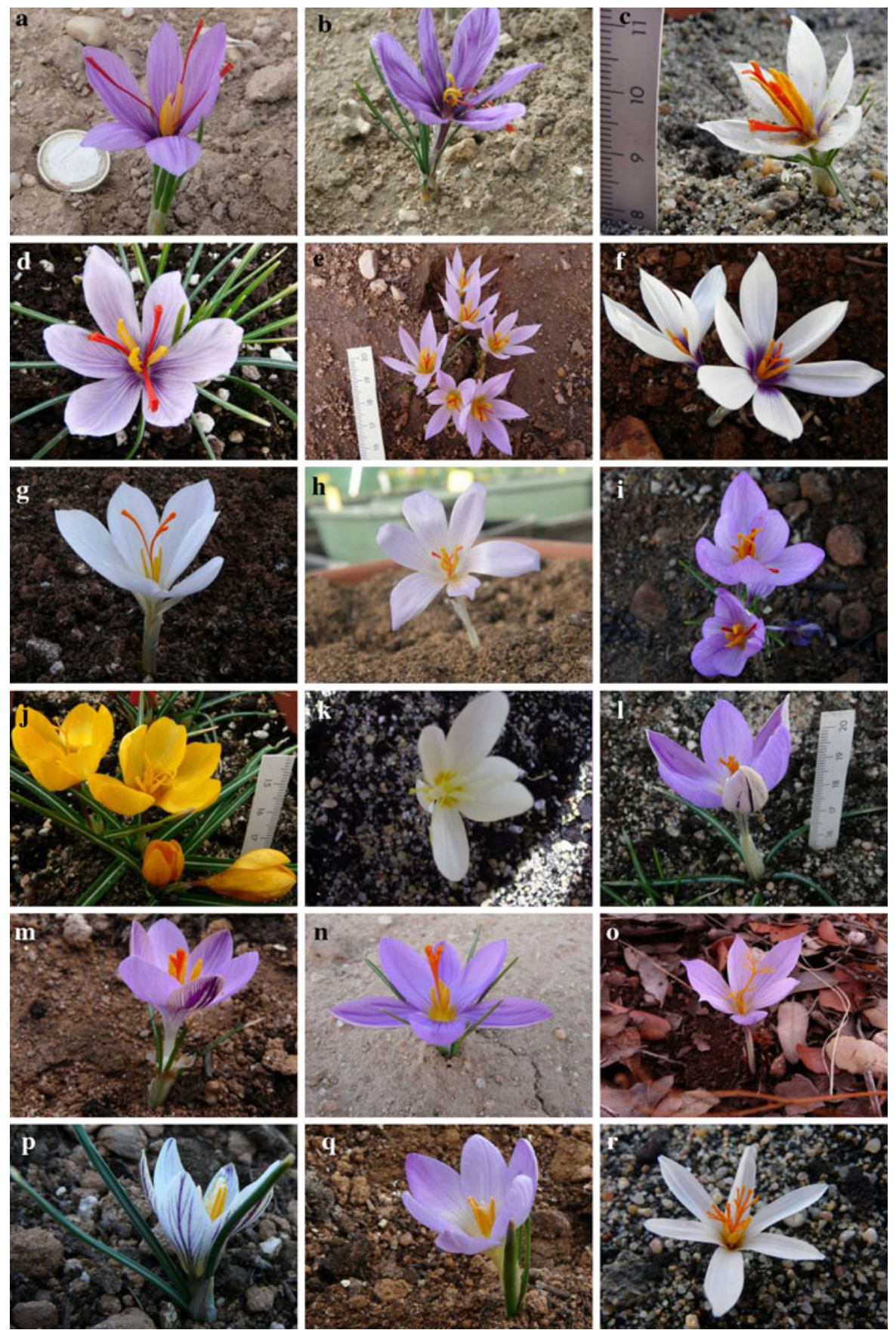

Fig. 2 Some of the wild Crocus preserved: a C. sativus L., b C. sativus L. var. cashmeriensis, c C. cartwrightianus Herb. cv. Albus, d C. cartwrightianus Herb., e C. hadriaticus Herb., f C. mathewii Kerndorff et Pasche, g C. asumaniae Mathew et Baytop, h C. pallasii Goldb., i C. thomasii Ten.,

a result of these efforts, nineteen (19) new species (subspecific taxonomic categories and commercial cultivars are not included in the statistics), that failed j C. kotschyanus Koch, $\mathbf{k}$ C. ochroleucus Boiss. et Gaill., l C. imperati Ten., m C. minimus DC., n C. corsicus Maw, o C. serotinus Salisb., p C. nevadensis Amo, q C. carpetanus Boiss. et Reut., $\mathbf{r}$ C. fleischeri Gay

to be acquired through collecting expeditions and donations, were included in the collection (Table 5). Taking into account the importance of the genus as a 
Table 1 Saffron (C. sativus L.) germplasm acquisition trips

\begin{tabular}{|c|c|c|c|c|}
\hline Year & Country & Collecting objectives & Principals & Expeditions \\
\hline 2006 & Morocco & Commercial area of Talliouine & UCLM (Spain) & 1 \\
\hline 2006 & Iran & Commercial areas of Khorasan & TJMT (France) & 4 \\
\hline $2006-2008$ & Spain & Commercial areas including DOP "Azafrán de La-Mancha" & $\begin{array}{l}\text { UCLM, UPVLC, } \\
\text { JCCM (Spain) }\end{array}$ & 32 \\
\hline $2006-2007$ & Spain & $\begin{array}{l}\text { Commercial areas of Teruel including DOPs (in course) "Azafranes del } \\
\text { Jiloca" and "Azafranes de Campo Bello" }\end{array}$ & $\begin{array}{l}\text { UCLM, UPVLC } \\
\text { (Spain) }\end{array}$ & 5 \\
\hline $2007-2010$ & Spain & Zones of minimal or relict production and/or abandoned fields in Spain & $\begin{array}{l}\text { UCLM, UPVLC, } \\
\text { JCCM (Spain) }\end{array}$ & 13 \\
\hline 2007 & Italy & $\begin{array}{l}\text { Commercial areas of Perugia and L'Aquila including DOP "Zafferano } \\
\text { dell'Aquila" }\end{array}$ & UNICIT (Italy) & 3 \\
\hline 2007 & Italy & $\begin{array}{l}\text { Commercial areas of Tuscany and Abruzzo including DOP "Zafferano } \\
\text { di San Gimignano" }\end{array}$ & UCLM (Spain) & 2 \\
\hline 2007 & Hungary & Relict Hungarian saffron from Csongrad and Pest megye & UD (Hungary) & 2 \\
\hline 2008 & Azerbaijan & Collection in relict areas of Aspheron & ANAS (Azerbaijan) & 2 \\
\hline 2008 & Greece & Commercial areas including DOP "Krokos Kozani" & NAGREF (Greece) & 1 \\
\hline 2008 & Turkey & Traditional areas of Safranbolu & GU (Turkey) & 2 \\
\hline 2008-2009 & France & Commercial areas of Quercy and Gâtinais & $\begin{array}{l}\text { INPT, TJMT } \\
\text { (France) }\end{array}$ & 10 \\
\hline 2009 & Italy & $\begin{array}{l}\text { Commercial areas of Medio Campidiano including DOP "Zafferano di } \\
\text { Sardegna" }\end{array}$ & UNICIT (Italy) & 1 \\
\hline 2010 & Greece & Commercial areas including DOP "Krokos Kozani" & $\begin{array}{l}\text { NAGREF, AUA } \\
\text { (Greece) }\end{array}$ & 2 \\
\hline 2010 & Morocco & Traditional cultivation area of Ourika Valley & UCLM (Spain) & 1 \\
\hline
\end{tabular}

source of ornamental plants we included some of the most priced cultivars grown as garden plants.

Germplasm ex situ conservation concerns and strategies

At present, the collection contains 572 accessions representing 47 Crocus species (subspecific taxonomic categories and commercial cultivars are not included in the statistics) from 18 countries. In this connection, the BGV-CU has two main objectives: the first involves material conserved for the medium and long term, with the aim of preserving the genetic information in the accession, and the second concern material currently in use or about to be used. The current status of the collection is summarized in Table 6 .

For many crops, but particularly the vegetatively propagated species, the development of new strategies, or extension of strategies to more genotypes (e.g. wild accessions) is needed for better conservation systems (Khoury et al. 2010). The experience gained during 3 years of conservation has guaranteed the representativeness of accessions through the different collections in the bank design as a good strategy for further exploitation of the collection (Table 7).

\section{Reserve vegetative collection}

This collection has been created for the long-term storage and preservation, the recovery of missing accessions during the multiplication process and the preservation of the germplasm at BGV-CU. No distribution or exchange of material is achieved from this collection. At present, all the collection in vegetative form (corms) is represented in the RSVC (see Table 7) including saffron (220 accessions) and other Crocus (251 accessions).

\section{Exchange vegetative collection}

It refers to the collection kept for medium-term preservation and it is responsible for implementing distribution and utilisation (characterisation and evaluation). Ideally, the collection must be maintained in sufficient quantities to be available to the users. Currently around $100 \%$ of saffron accessions 
Table 2 Wild Crocus germplasm acquisition trips, nomenclature according to Mathew (1982)

\begin{tabular}{|c|c|c|c|c|}
\hline Year & Country & Collecting objectives & Principals & Expeditions \\
\hline 2006-2010 & Spain & $\begin{array}{l}\text { C. serotinus Salisb. ssp. clusii (Gay) Mathew \& ssp. } \\
\text { salzmanii (Gay) Mathew, C. carpetanus Boiss. et Reut., } \\
\text { C. nevadensis Amo, C. nudiflorus } \mathrm{Sm} \text {. C. vernus (L.) Hill } \\
\text { ssp. albiflorus (Kit.) Asch. et Graebner, C. cambessedessi } \\
\text { Gay }\end{array}$ & $\begin{array}{l}\text { UPVLC, UCLM, } \\
\text { JCCM (Spain) }\end{array}$ & 40 \\
\hline 2006-2007 & Romania & $\begin{array}{l}\text { C. vernus (L.) Hill ssp. vernus (=C. heuffelianus Herb.), } \\
\text { C. banaticus Gay }\end{array}$ & UD (Hungary) & 7 \\
\hline 2006-2007 & Ukraine & $\begin{array}{l}\text { C. vernus (L.) Hill ssp. vernus (=C. heuffelianus Herb.), } \\
\text { C. banaticus Gay }\end{array}$ & UD (Hungary) & 2 \\
\hline 2006 and 2008 & Turkey & C. ancyrensis (Herb.) Maw, C. speciosus Bieb. & GU (Turkey) & 2 \\
\hline 2007 & Slovaquia & $\begin{array}{l}\text { C. vernus (L.) Hill ssp. vernus (=C. scepusiensis Rehm. } \\
\text { et Wol.) }\end{array}$ & UD (Hungary) & 1 \\
\hline 2007 & Hungary & $\begin{array}{l}\text { C. vernus }(\text { L.) Hill ssp. vernus }(=C \text {. vittatus Schloss et } \\
\text { Vukot), C. tommasinianus Herb., C. reticulatus Stev. ex } \\
\text { Adams ssp. reticulatus, C. vernus (L.) Hill ssp. vernus } \\
\text { (=C. heuffelianus } \text { Herb.) }\end{array}$ & UD (Hungary) & 4 \\
\hline $2007-2009$ & Italy & $\begin{array}{l}\text { C. thomasii Ten., C. vernus (L.) Hill ssp. vernus et ssp. } \\
\text { albiflorus (Kit.) Asch. et Graebner, C. imperati Ten. ssp. } \\
\text { imperati, C. longiflorus Raf., C. biflorus Mill. ssp. biflorus } \\
\text { \& ssp. weldenii (Hoppe et Fürnr.) Mathew, C. ligusticus } \\
\text { Mariotti, C. etruscus Parl., C. versicolor Ker Gawl. }\end{array}$ & UNICIT (Italy) & 16 \\
\hline 2008 & Azerbaijan & $\begin{array}{l}\text { C. biflorus Mill. ssp. adamii (Gay) Mathew, C. caspius } \\
\text { Fisch. et Mey, C. speciosus Bieb. ssp. speciosus }\end{array}$ & ANAS (Azerbaijan) & 4 \\
\hline 2008 & Greece (Cyprus) & C. cyprius Boiss. et Kotschy, C. hartmannianus Holmboe & NAGREF (Greece) & 1 \\
\hline 2008-2010 & Greece & $\begin{array}{l}\text { C. hadriaticus Herb. ssp. hadriaticus \& parnassicus } \\
\text { (Mathew) Mathew, C. cartwrightianus Herb., C. sieberi } \\
\text { Gay ssp. sublimis (Herb.) Mathew \& atticus Boiss. et } \\
\text { Orph., C. pulchellus Herb., C. veluchensis Herb., } \\
\text { C. goulimyi Turril ssp. goulimyi \& ssp. leucanthus } \\
\text { (Mathew) Mathew, C. boryi Gay, C. cvijicii Košanin, } \\
\text { C. tourneforti Gay, C. niveus Bowles, C. olivieri Gay }\end{array}$ & NAGREF (Greece) & 24 \\
\hline
\end{tabular}

and $77 \%$ of other Crocus accessions are represented in EXVC (Table 7).

\section{Seed collection}

Due to the biological characteristics of Crocus species, the collection is maintained and reproduced basically in a vegetative way. However, we have preserved seeds of 101 accessions from 20 different Crocus taxa (Table 7).

Germplasm documentation

Documentation of information on Plant Genetic Resources (PGR) is imperative for planning and implementing activities related to their conservation, sustainable utilisation and sharing of benefits accrued from their use (Agrawal et al. 2007). The need of maintaining and exchanging such information is specifically recognized in Articles $7 \mathrm{~d}$ and 17 of the Convention of Biological Diversity (CBD 1993). The design of global information database, are of extreme importance to the conservation and use of collections (Wallace et al. 2008; Pandey et al. 2008; Ravisankar et al. 2008; Upadhyaya et al. 2008; Khoury et al. 2010). The conversion of off-line database to a searchable online database is a high priority on acting to build better information systems (Khoury et al. 2010).

\section{Database implementation and descriptions (back-end application)}

A specific relational database with 28 related tables, 20 data entry forms, 2 reports, and 60 queries based on the passport and management descriptors 
Table 3 Germplasm donations from botanical gardens recorded since 2006 in the BGV-CU, Spain, nomenclature according to Mathew (1982)

\begin{tabular}{|c|c|c|}
\hline Institution & Germplasm & Accessions \\
\hline $\begin{array}{l}\text { Conservatoire et Jardin Botaniques de la Ville } \\
\text { Genéve (Switzerland) }\end{array}$ & $\begin{array}{l}\text { C. vernus (L.) Hill. ssp. albiflorus (Kit.) Asch. } \\
\text { et Graebner }\end{array}$ & 1 \\
\hline Nationale Plantentuin van België (Belgium) & C. kotschyanus Koch. ssp. kotschyanus, C. flavus Weston & 2 \\
\hline Botanic Garden Utrecht University (Netherlands) & $\begin{array}{l}\text { C. ochroleucus Boiss. et Gaill., C. vernus (L.) Hill, } \\
\text { C. speciosus Bieb., ssp. speciosus, C. banaticus Gay }\end{array}$ & 3 \\
\hline $\begin{array}{l}\text { Jardin des Plantes Médicinales et Aromatiques. } \\
\text { Marie de Chemille (France) }\end{array}$ & C. sativus $\mathrm{L}$. & 1 \\
\hline $\begin{array}{l}\text { Conservatoire Botanique National de Brest } \\
\text { (France) }\end{array}$ & C. goulimyi Turrill & 1 \\
\hline $\begin{array}{l}\text { Niels Jacobsen. The Royal Veterinary and } \\
\text { Agricultural University (Denmark) }\end{array}$ & $\begin{array}{l}\text { C. cartwrightianus Herb., C. hadriaticus Herb., } \\
\text { C. goulimyi Turrill, C. cancellatus Herb. ssp. } \\
\text { mazziaricus (Herb.) Mathew }\end{array}$ & 12 \\
\hline Ljubljana University Botanic Garden (Slovenia) & C. pulchellus Herb. & 1 \\
\hline $\begin{array}{l}\text { Jardin alpin du Lautaret, Université Joseph } \\
\text { Fourier, Grenoble I (France) }\end{array}$ & C. vernus (L.) Hill & 2 \\
\hline Herbario SANT (Spain) & C. serotinus Salisb. ssp. salzmanii (Gay) Mathew & 1 \\
\hline
\end{tabular}

Table 4 Donations of saffron germplasm from private companies, producers and/or traditional farmers

\begin{tabular}{lllcc}
\hline Year & Country & Donation objectives & Intermediaries & Accessions \\
\hline 2006 & New Zealand & Micro-scale productions of Rangiora & UCLM (Spain) & 1 \\
2006 & Argentina & Commercial areas of Atos-Pampa, Córdoba & UCLM (Spain) & 1 \\
2006 & United Kingdom & Zones of minimal relic production in Cambridge & UCLM (Spain) & 2 \\
2007 & Italy & Commercial areas including DOP “Zafferano di Sardegna” & UCLM (Spain) & 1 \\
2007 & India & Commercial areas of Jammu and Kashmir & UCLM (Spain) & 1 \\
2008 & Afghanistan & Commercial areas of Herat & UCLM (Spain) & 1 \\
2009 & Switzerland & Ancient productions of Mund including DOP “Munder Safran” & UCLM (Spain) & 6 \\
2010 & France & Saffron commercial lands of Limousin & UCLM (Spain) & 1 \\
\hline
\end{tabular}

mentioned above has been prepared. A control panel (main menu) with a series of user-friendly menus was designed in order to facilitate the accurate updating of database and to provide easy access to stored information. A link to photographic documentation and phenology behaviour of each accession has been included.

The database comprises the following categories:

a) Accession passport descriptors: 25 descriptors including identification data related to the registration of the sample at the germplasm bank.

b) Collecting passport descriptors: 26 descriptors providing detailed information regarding the conditions prevailing at the species-specific habitat in the natural environment. c) Management: 20 descriptors are being recorded providing detailed information regarding the current status of conservation and multiplication of each accession through the different collections.

d) Characterisation/Evaluation: A database structure with specific fields is being prepared to include characterisation data after publication.

\section{Web interface (front-end application)}

Documentation systems through internet enable rapid dissemination of the database information to users. In this connection, we developed and currently manage the CIS (Santana et al. 2010). The web interface 
Table 5 New Crocus species incorporated in the BGV-CU from nurseries, nomenclature according to Mathew (1982)

\begin{tabular}{llll}
\hline Species & $\begin{array}{l}\text { Accessions } \\
\text { acquired }\end{array}$ & Nursery & Principals \\
\hline C. asumaniae Mathew et Baytop & 2 & JW Dix Export (The Netherlands) & ULEIST (United Kingdom) \\
C. corsicus Vanucci & 1 & Pottertons Nursery (United Kingdom) & UCLM (Spain) \\
C. dalmaticus Vis. & 1 & Pottertons Nursery (United Kingdom) & UCLM (Spain) \\
C. fleischeri Gay & 1 & Pottertons Nursery (United Kingdom) & UCLM (Spain) \\
C. korolkowii Regel ex Maw & 1 & Pottertons Nursery (United Kingdom) & UCLM (Spain) \\
C. kosaninii Pulević & 1 & Pottertons Nursery (United Kingdom) & UCLM (Spain) \\
C. kotschyanus Koch. & 1 & Broadleigh Gardens (United Kingdom) & UCLM (Spain) \\
C. laevigatus Bory et Chaub. & 1 & Pottertons Nursery (United Kingdom) & UCLM (Spain) \\
C. malyi Vis. & 1 & Pottertons Nursery (United Kingdom) & UCLM (Spain) \\
C. mathewii Kerndorff et Pasche & 1 & Pottertons Nursery (United Kingdom) & UCLM (Spain) \\
C. medius Balb. & 1 & Broadleigh Gardens (United Kingdom) & UCLM (Spain) \\
C. oreocreticus Burtt & 2 & JW Dix Export (The Netherlands) & ULEIST (United Kingdom) \\
C. pallasii Goldb. & 5 & JW Dix Export (The Netherlands) & ULEIST (United Kingdom) \\
C. pestalozzae Boiss. & 1 & Pottertons Nursery (United Kingdom) & UCLM (Spain) \\
C. tournefortii Gay & 1 & Pottertons Nursery (United Kingdom) & UCLM (Spain) \\
C. vitellinus Wahlenb. & 1 & Pottertons Nursery (United Kingdom) & UCLM (Spain)
\end{tabular}

Table 6 Current status of the WSCC at the BGV-CU, Cuenca, Spain

\begin{tabular}{llll}
\hline Genetic Material & $\begin{array}{l}\text { Accessions }_{\text {acquired }^{\text {a }}} \\
\text { Saffron (C. sativus) }\end{array}$ & $\begin{array}{l}\text { Accessions } \\
\text { Preserved }^{\text {a }}\end{array}$ & Countries of origin \\
$\begin{array}{c}\text { Other Crocus (47 } \\
\text { species confirmed) }\end{array}$ & 429 & 220 & $\begin{array}{c}\text { Afghanistan, Argentina, Azerbaijan, Spain, France, Greece, Hungary, India, } \\
\text { Iran, Italy, Morocco, New Zealand, United Kingdom, Switzerland, Turkey }\end{array}$ \\
$\begin{array}{l}\text { Total } \\
\text { Azerbaijan, Slovakia, Spain, France, Greece, Hungary, Italy, United Kingdom, } \\
\text { Romania, Switzerland, Turkey, Ukraine }\end{array}$ \\
\hline
\end{tabular}

${ }^{a}$ Differences between acquired and preserved accessions are due to losses during acquisition and/or management the materials

Table 7 Summarized ex situ conservation design and distribution strategy of the germplasm accessions at BGV-CU

\begin{tabular}{llll}
\hline & RSVC & EXVC & SC (wild taxa) \\
\hline Objectives & Long-term conservation & Multiplication and distribution & Medium-term conservation \\
Conservation conditions & Greenhouse & In farm & Hermetic jars \\
Optimum quantity & 10 corms & 40 corms & $>1,000$ seeds \\
Saffron accessions & 220 & 220 & - \\
Other Crocus accessions & 251 & 192 & 101 \\
\hline
\end{tabular}

(http://www.crocusbank.org/Information\%20System. html) comprises all the BGV-CU services subdivided in two main subsections:

a) Connections to a database in order to provide:

- Information related to the passport descriptors executing queries through direct links and/or searching in the database (http://www.crocus bank.org/Database/ buscador.asp),

- Information about the management of descriptors as the basis for further queries in order to inform on the availability of preserved materials and future request of accessions (http://www.crocus bank.org/Database/ConsultBulbsAvailability.asp), 
- A summary of the characterisation descriptors recorded in the collection (will be available on Internet after publication).

b) Other BGV-CU services to the final users, including methodologies and protocols, interactive maps of current saffron producing areas and distribution of taxa in the genus Crocus (http://www. crocusbank.org/ammap_2.1.0/examples/drill_down/ SaffronAreasMapNew.html), a review of the literature about saffron and other Crocus (http://www. crocusbank.org/Login.asp), documents related to the management of genetic resources and a photographic documentation of activities and actions made so far (http://www.crocusbank.org/GGallery.html).

\section{Database on-line searches}

Through the path: http://www.crocusbank.org/Data bse/buscador.asp, users can search all the information available from the CIS by identifying one or more of about 26 passport data of the accessions preserved. The text input files are set by default for an exact match (without accents, swung dash or other special characters). These searches can be modified to find records containing any part of the text the user needs to find. Complex queries can be executed integrating data from multiple passport data (Santana et al. 2010).

\section{Germplasm distribution}

A basic criterion for supplying plant materials including dates of request and sending has been established based on phenology of the materials and facilities at the BGV-CU. At the short time the provision of genetic materials (corms, leaves, styles, anthers and seeds) is addressed to carry out the complete characterisation/ evaluation of the collection. From the next 2 years users can consult the availability of materials (through the CIS or by contacting the curator) in order to request accessions. Before the user receives the materials a Material Transfer Agreement between donor and recipient must be signed.

\section{Germplasm characterisation}

\section{Descriptor definition}

A descriptor list for whole characterisation and evaluation of the genus has been defined and improved during the last 3 years (unpublished data). It includes characterization descriptors (95 traits), evaluation descriptors (47 traits) and descriptors based on genetic markers technologies and cytological characters (14 traits), and embraces a diverse set of data (morphological, phenological, agronomical, phytochemical, molecular, etc.), with the aim of being a useful tool for the description of the genetic variation in the genus Crocus.

\section{Characterisation/evaluation}

Germplasm characterisation is an important operation for a genebank since the value of the germplasm collection depends on the availability and quality of the information relative to the preserved accessions. Therefore, one of the main goals of CROCUSBANK action is to strategically characterize and evaluate germplasm of saffron and allies at different levels. A partial characterisation/evaluation of the collection have been developed during last years taking into account morphological, phenological, agronomical, resistance to salt stress, phytochemical, and molecular characters.

Sixty-six (66) saffron accessions have been characterised/evaluated for morphological, phenological and agronomical traits, and the existence of variability has been observed, suggesting the existence of genetic differences among the accessions related to the geographic origin of the materials (unpublished data). These preliminary results are being confirmed by the data obtained in other approaches. A different sensitiveness to saline stress has been recorded among some of the above mentioned saffron accessions in relation to genotypes origin (unpublished data). The phytochemical analysis using gas chromatography (GC-MS) and/or spectroscopic methods (FT-IR, Raman) also indicates that potential variability occurs among saffron accessions (unpublished data). In the same way genomic AFLP and SNPs markers have been identified in a subset of accessions, showing clearly the existence of genetic variation in saffron crop (unpublished data). In addition, these genetic markers provide a specific genetic fingerprint that could be very useful for the rationalisation of the bank.

The significant genetic variability found in saffron, evidenced with the on-going characterisation/evaluation studies, opens the door to unravel the 
Table 8 Priority actions and future prospects in the WSCC

\begin{tabular}{|c|c|}
\hline Action category & Future prospect \\
\hline Collection & $\begin{array}{l}\text { High priority should be given on obtaining some Crocus taxa not represented in the WSCC or missed } \\
\text { in previous acquisitions }\end{array}$ \\
\hline Preservation & $\begin{array}{l}\text { Efforts need to be focused on management of ex situ conservation and multiplication of crops, wild } \\
\text { relatives and local varieties (e.g. in vitro conservation) }\end{array}$ \\
\hline Characterisation & $\begin{array}{l}\text { An extensive characterisation of the WSCC materials including agro-morphological, phenological, } \\
\text { chemical, molecular and cytogenetical descriptors will allow performing analyses regarding the } \\
\text { variability among and within populations }\end{array}$ \\
\hline $\begin{array}{l}\text { Evaluation and genetic } \\
\text { enhancement }\end{array}$ & $\begin{array}{l}\text { A coordinated and integrated effort to evaluate the WSCC is needed to identify useful genotypes (e.g. } \\
\text { sources of biotic and abiotic tolerance, genotypes with optimal production of secondary metabolites, } \\
\text { genotypes interesting for improving saffron yield, etc.) }\end{array}$ \\
\hline $\begin{array}{l}\text { Rationalization of the } \\
\text { collection }\end{array}$ & $\begin{array}{l}\text { The reduction of the collection size, without loss in the genetic variability is a very desirable approach } \\
\text { in order to preserve the collection and to promote its utilisation (e.g. creation of a core collection) }\end{array}$ \\
\hline $\begin{array}{l}\text { Utilisation and } \\
\text { dissemination }\end{array}$ & $\begin{array}{l}\text { A new more dynamic portal exclusively for the WSCC utilisation and disseminations is being } \\
\text { designed. It's based on Joomla CMS (www.joomla.org) and MySQL database with allows large } \\
\text { numbers of people to contribute and share stored data and to improve communication between users } \\
\text { through blogs, forums, etc. }\end{array}$ \\
\hline
\end{tabular}

peculiarities of "land varieties" of this minor but highly appreciated Mediterranean crop. Accordingly, these results scientifically support the importance of conserving the local and precious cultivated germplasm worldwide.

Similar studies have been programmed or are being developed indeed for other Crocus species integrated in the WSCC, however, the shortage of materials in most accessions is by the moment a limiting factor to develop more extensive studies. Anyway, preliminary trials considering different kind of traits (mainly morphological, phenological and molecular, but also salt stress resistance, and phytochemical in a lesser extent), have revealed both, interspecific and intraspecific variability, in 34 accessions belonging to 21 species (unpublished data). That information may be of interest for different purposes (commercial gardening, bank rationalisation, taxonomic or evolution studies, etc.), although much work remains to be done in the future with these materials.

Future actions and prospects on the WSCC

The WSCC has already a wide representation of the Crocus germplasm of plausible utility in saffron breeding which has never been achieved before. Additionally, for the first time worldwide it has been created a unique collection which contains a large part of the variability of the saffron crop and wild relatives at global scale for common use. Therefore, priority actions to make useful the genetic resources to potential users are needed as outlined in Table 8.

Acknowledgments Many of the results presented in this paper are an outcome of the project "Genetic Resources of Saffron and Allies" (CROCUSBANK, http://www.crocusbank. org). This action receives financial support from the European Commission, Directorate General for Agriculture and Rural Development, under the Council Regulation (EC) No. 870/ 2004 establishing a Community Programme on the conservation, characterisation, collection, and utilisation of genetic resources in Agriculture (018 AGRI GEN RES ACTION). In addition some of the activities presented took a long period of time and have been partially supported by the following projects or actions: RFP-1 (Consejería de Agricultura, JCCM, Spain), 05-172/IA-35 (Consejería de Agricultura, JCCM, Spain), PAI09-0021-0413 and PBI09-0025-1537 (Consejería de Educación y Ciencia, JCCM, Spain), RF2008-0012-C03 (Instituto Nacional de Investigación y Tecnología Agraria y Alimentaria, MEC, Spain), RF2004-0032-C03 (Instituto Nacional de Investigación y Tecnología Agraria y Alimentaria, MEC, Spain). Special thanks to the following donor's institutions: Regulatory Council for the "La Mancha Saffron" designation of origin (DOP, La Mancha, Spain); The Royal Veterinary and Agricultural University (Denmark); Asociación de Naturalistas del Sureste (ANSE, Spain); Centro de Investigación y Tecnología Agroalimentaria de Aragón (CITA, Spain); MTS Schipper \& Elberse (Holland); Botanic Garden Utrecht University (The Netherlands); National Botanic Garden of Belgium (Belgium); Jardin Alpin du Lautaret (France); Frega S.R.L. (Argentina); Conservatoire et Jardin Botaniques de la Ville Genéve (Switzerland); Herbario Sant (Spain); Conservatoire Botanique National de Brest (France); Jardin des Plantes Médicinales et Aromatiques (France); Baby Brand Saffron (India); Azienda Agrícola di Di Marco Amalia (Italy); 
Azienda Agrícola IL Vecchio Maneggio (Italy); New Zealand Institute for Crop and Food Research (New Zealand); Ljubljana University Botanic Garden (Slovenia) and the Afghanistan Government. We thank very much the traditional saffron growers of different countries (Spain, France, Greece, Italy, Iran, Morocco, etc.), associations, companies, researchers, forest rangers and all the people who have contributed with materials included in the collection (for more detailed information see the website www.crocusbank.org).

Open Access This article is distributed under the terms of the Creative Commons Attribution Noncommercial License which permits any noncommercial use, distribution, and reproduction in any medium, provided the original author(s) and source are credited.

\section{References}

Abdullaev FI (2002) Cancer chemopreventive and tumoricidal properties of saffron (Crocus sativus L.). Exp Biol Med Maywood 227:20-25

Abdullaev FI (2004) Antitumor effect of saffron (Crocus sativus L.). Overview and perspectives. Acta Hort (ISHS) 650:491-499

Abdullaev FI, Espinosa-Aguirre JJ (2004) Biomedical properties of saffron and its potential use in cancer therapy and chemoprevention trials. Cancer Detect Prev 28:426-432

Agrawal RC, Behera D, Saxena S (2007) Genebank information management system (GBIMS). Comput Electron Agric 59:90-96

Arslan N, Ozer AS, Akdemir R (2007) Cultivation of saffron (Crocus sativus L.) and effects of organic fertilizers to the flower yield. Acta Hort (ISHS) 826:237-240

Bioversity International (2007) Guidelines for the development of crop descriptor list. Bioversity Technical Bulletin Series. Bioversity International. Rome, Italy, Xii $+72 \mathrm{p}$

CBD (1993) Convention on biological diversity. http://www. biodiv.org/convention/articles.asp

Dalezis P, Papageorgiou E, Geromichalou E, Geromichalus G (2009) Antitumor activity of crocin, crocetin and safranal on murine P388 leukemia bearing mice. In: 3rd International symposium on saffron Forthcoming challenges in cultivation research and economics. Krokos, Kozani, Greece 58. Book of Abstracts, p 58

De-Los-Mozos-Pascual M, Roldán M, Fernández JA (2010a) Preserving biodiversity in saffron: the CROCUSBANK project and the world saffron and Crocus collection. Acta Hort (ISHS) 850:23-28

De-Los-Mozos-Pascual M, Santana O, Rodríguez MF, Sánchez R, Pastor T, Sanchís E, García A, Guardiola JL, Molina RV, Medina J, Fernández JA (2010b) Current state of the Spanish germplasm collection of saffron and wild relatives. Acta Hort (ISHS) 850:303-308

De-Los-Mozos-Pascual M, Santana O, Rodríguez MF, Sánchez R, Pastor T, Fernández JA, Santaella M, Sánchez RA, Verwulgen T, Palacios M, Renau B, Sanchís E, García A, Guardiola JL, Molina RV (2010c) A preliminary characterisation of saffron germplasm from the CROCUSBANK collection. Acta Hort (ISHS) 850:35-40
Engels JMM, Visser L (eds) (2003) A guide to effective management of germplasm collections. IPGRI Handbooks for Genebanks No 6. IPGRI, Rome, Italy

Fernández JA (2004) Biology, biotechnology and biomedicine of saffron. Recent Res Dev Plant Sci 2:127-159

Fernández JA (2007) Genetic resources of saffron and allies (Crocus spp.). Acta Hort (ISHS) 739:167-185

Goldblatt P, Davies TJ, Manning JC, van der Bank M, Savolainen V (2006) Phylogeny of Iridaceae subfamily Crocoideae based on a combined multigeneplastid DNA analysis. Aliso 22:399-411

Khoury C, Laliberté B, Guariano L (2010) Trends in ex situ conservation of plant genetic resources: a review of global crop and regional conservation strategies. Genet Resour Crop Evol 57:625-639

Mathew B (1977) Crocus sativus and its allies (Iridaceae). Plant Syst Evol 128:89-103

Mathew B (1982) The Crocus. A revision of the genus Crocus (Iridaceae). Timber Press, Portland

Maxted N, Scholten M, Codd R, Ford-Lloyd B (2007) Creation and use of national inventory of crop wild relatives. Biol Conserv 140:142-159

Pandey A, Pandey R, Negi KS, Radhamani J (2008) Realizing value of genetic resources of Allium in India. Genet Resour Crop Evol 55:985-994

Petersen G, Seberg O, Thorsoe S, Jorgensen T, Mathew B (2008) A phylogeny of the genus Crocus (Iridaceae) based on sequence data from five plastid regions. Taxon 57:487-499

Radjabian T, Ghazanfari T, Daniali F (2009) The effect of crocetin on cell-mediated immunity in BALB/c mice. In: 3rd International symposium on saffron "Forthcoming challenges in cultivation research and economics. Krokos, Kozani, Book of Abstracts, p 57

Rashed-Mohassel MH (2007) Saffron from the wild to the field. Acta Hort (ISHS) 739:187-193

Ravisankar H, Sarala K, Krishnamurthy V, Rao RVS (2008) A software system for tobacco germplasm data. Plant genetic resources: Characterisation and Utilisation 1-4

Santana O, De-Los-Mozos-Pascual M, Fernández JA (2010) Public disclosure, interpretation and displaying the "World Saffron and Crocus Collection" through the CROCUSBANK website. Acta Hort (ISHS) 850:95-98

Tsoktouridis G, Krigas N, Karamplianis T, Constantinidis T, Maloupa E (2009) Genetic differences among wild Greek Crocus taxa and cultivated saffron (Crocus sativus L.). In: 3rd International symposium on saffron Forthcoming challenges in cultivation research and economics. Krokos, Kozani, Greece Book of Abstracts, p 37

Upadhyaya HD, Gowda CLL, Pundir RPS, Gopal Reddy V, Singh Sube (2006) Development a core subset of finger millet germplasm using geographical origin and data on 14 quantitative traits. Genet Resour Crop Evol 53:679-685

Upadhyaya HD, Gowda CLL, Sastry DVSSR (2008) Plant Genetic resources management: collection, characterisation, conservation and utilisation. J SAT Agric Res 6:1-16

Wallace TP, Bowman D, Campbell BT, Chee P, Gutierrez OA, Kohel RJ, McCarty J, Myers G, Percy R, Robinson F, Smith W, Stelly DM, Stewart JM, Thaxton P, Ulloa M, Weaver DB (2008) Status of the USA cotton germplasm collection and crop vulnerability. Genet Resour Crop Evol 56:507-532 